\title{
Decreases in Concentrations and Human Dietary Intakes of Polychlorinated Biphenyls (PCBs) and Polybrominated Diphenyl Ethers (PBDEs) in Korean Seafood Between 2005 and 2017
}

\author{
Minkyu Choi \\ National Institute of Fisheries Science \\ In-seok Lee ( $\boldsymbol{\sigma}$ islee@korea.kr) \\ National Institute of Fisheries Science https://orcid.org/0000-0002-6334-8405
}

\section{Original Research}

Keywords: Polychlorinated biphenyls, dioxin-like PCBs, polybrominated diphenyl ethers, temporal trend, decrease

Posted Date: February 1st, 2021

DOI: https://doi.org/10.21203/rs.3.rs-163844/v1

License: (9) (1) This work is licensed under a Creative Commons Attribution 4.0 International License. Read Full License 


\section{Abstract}

Concentrations of PCBs and PBDEs were measured in 23 seafood species widely consumed by Korean population in 2005-2007, 2010-2011, and 2015-2017. The $\Sigma_{82}$ PCB and $\Sigma_{19} P B D E$ concentrations in the seafood samples of $2015-2017$ were $0.06-6.69 \mathrm{ng} / \mathrm{g}$ wet weight and $0.01-1.60 \mathrm{ng} / \mathrm{g}$ wet weight, respectively. The $\Sigma_{82} \mathrm{PCB}$ and $\Sigma_{19} \mathrm{PBDE}$ concentrations in the samples were correlated significantly, and elevated PCB and PBDE concentrations were found in fatty fish such as herring, mackerel, and tuna. The current intakes of PCBs and PBDEs were much lower than a TDI or a LOAEL. The levels and human dietary intakes of PCBs and PBDEs in the $2015-2017$ survey showed decreases of $17-73 \%$ and $57-86 \%$, respectively, in relation to the 2005-2007 and 2010-2011 surveys. This indicates that global bans on PCBs and PBDEs have been effective, and their levels and exposure have been gradually declining.

\section{Introduction}

Polychlorinated biphenyls (PCBs) and polybrominated diphenyl ethers (PBDEs) are persistent organic pollutants (POPs) that accumulate in organisms and are biomagnified through food chains with elevated levels in top predators (Moon et al. 2010). These contaminants can cause adverse health effects such as dermal toxicity, immunotoxicity, reproductive deficits, teratogenicity and endocrine interferences (Ankarberg et al. 2007). Use of POPs has been banned globally according to Stockholm convention on POPs, and PCBs and PBDEs were classified as POPs in 2005 and 2009, respectively (Convention 2008). In Korea, approximately 4,300 tons of PCBs were used until the 1990s, and the use of PCBs was banned (Moon et al. 2009). In Korea, PBDEs have been widely used as brominated flame retardants. Usage of deca-BDE in Korea in 2002 was 12,324 tons, while usage of penta- and octa-BDEs together was 84 tons. Penta- and octa-BDE were banned in 2008, and deca-BDE was not restricted, but according to voluntary phase out, usage of deca-BDE in Korea was decreased to 1,405 ton in 2010 (MOE 2015). As PBDEs are not bonded into materials but simply blended with the polymers, they are likely to be released into the environment and entering biological tissues through food chains. These contaminants are still found in seafood as well as coastal environments, and are considered to pose a substantial risk for human health (Leng et al. 2014). The recent concern now is to check the effectiveness of the global bans and efforts in terms of how fast the POPs such as PCBs and PBDEs in environmental levels and risks decline in the world.

A temporal trend study is an essential tool for assessing the effectiveness of legislative action on target contaminants in the environment (Jeong et al. 2016; Toms et al. 2018). However, little is known about temporal trends of dietary exposures of POPs such as PCBs and PBDEs associated with seafood consumption. In 2005-2007 and 2010-2011, we investigated, for nationwide baseline study, seafood contaminations focused on determining the concentration of POPs including PCBs and PBDEs in seafood most consumed by Korean population. Subsequently, the exposures of PCBs and dioxin-like PCBs (DL-PCBs) via seafood consumption were estimated to $4.4 \mathrm{ng} / \mathrm{kg} \mathrm{bw} /$ day and $0.9 \mathrm{pg}-\mathrm{TEQ} / \mathrm{kg}$ bw/day, respectively (Moon and Choi 2009; Moon et al. 2009). In 2010-2011, the exposures of PBDEs via seafood intake was estimated to $0.4 \mathrm{ng} / \mathrm{kg}$ bw/day (MLTM 2012). In order to investigate temporal trend of levels and the total dietary exposures to PCBs and PBDEs, the same seafood groups (fish, crustaceans, cephalopods, and bivalves) were again collected and analyzed from 2015 to 2017. We investigated the current levels of 82 PCBs and 19 PBDEs in seafood and their dietary intakes via seafood, and the comparison of the present situation with the previous baseline studies.

\section{Materials And Methods}

\subsection{Sample collection}

31 marine species (fish, shellfish, crustaceans, cephalopods, bivalves and gastropods) were selected among those most commonly consumed and commercially important species in Korea, and were caught in the Yellow Sea, South Sea, and East Sea areas of Korea, as in our previous nationwide survey (MLTM 2012; Moon and Choi 2009; Moon et al. 2009). 31 marine species $(n=230)$ were annually collected twice or three times from the Busan cooperative fish market, which is the largest fish market in South Korea and the representative market covering the whole country, along with information on fishing areas and vessels. Collected samples were stored in a cooler box with ice and immediately transported to the laboratory. After removing the skin of the fish and cephalopods, the muscles and tissues were homogenized using an ultra-disperser. The shells of the bivalves, gastropods and crustaceans were removed, and the whole soft tissues were pooled and homogenized for analysis. For PCBs and PBDEs analyses, two or three composite samples were prepared for each seafood item for each year $(n=230)$. Each composite sample consisted of more than 20 individual units for fish, crustaceans, cephalopods, and 100 individual units for bivalves. Only edible parts of each seafood were included in the composites.

\subsection{Chemical analysis}

82 PCB congeners including 12 DL-PCB congeners (CB-77, 81, 105, 114, 118, 123, 126, 156, 157, 167, 169 and 189) and 6 Non Dioxin-Like (NDL)PCB congeners (CB-28, 52, 101, 138, 153, 180), and 19 PBDE congeners (BDE-17, 28, 47, 49, 66, 71, 77, 85, 99, 100, 119, 126, 138, 153, 154, 156, 183, 184 , and 191) were analyzed in seafood samples. $82 \mathrm{PCB}$ stock standard solution, $35{ }^{13} \mathrm{C}_{12}$-labelled PCBs for surrogate standards, and seven ${ }^{13} \mathrm{C}_{12}{ }^{-}$ labelled PCBs for internal standards were purchased from Wellington (Guelph, ON, Canada). 19 PBDE stock standard solution, eleven ${ }^{13} \mathrm{C}_{12}$-labelled PBDEs for surrogate standards, and the ${ }^{13} \mathrm{C}_{12}$-labelled PBDE (BDE-138) for an internal standard were purchased from Wellington (Guelph, ON,

Canada). 
Analyses of PCBs and PBDEs in seafood were performed according to the methods described elsewhere (Moon and Choi 2009; Moon et al. 2009). The edible tissues (approximately $50 \mathrm{~g}$ ) were digested in $200 \mathrm{~mL}$ of $1 \mathrm{~N}$ ethanolic $\mathrm{KOH}$ solution (Wako Pure Chemicals, Tokyo, Japan) for $2 \mathrm{~h}$ by mechanic shaking. The surrogate standards for PCBs and PBDEs were spiked into the samples before the digestion process. The alkaline solutions were extracted twice with $150 \mathrm{~mL}$ of hexane (Ultra residue analysis, J.T.Baker, Phillipsburg, NJ, USA). The extracts were washed with purified water and then dried over $50 \mathrm{~g}$ of anhydrous $\mathrm{Na}_{2} \mathrm{SO}_{4}$ and subsequently reduced to $10 \mathrm{~mL}$ by rotary evaporation. Purification of PCBs and PBDEs was performed using multi-layer silica gel column containing $\mathrm{Na}_{2} \mathrm{SO}_{4}$ anhydrous $(4 \mathrm{~g}), 10 \% \mathrm{AgNO}_{3}$ silica gel $(3 \mathrm{~g})$, silica gel $(0.6 \mathrm{~g}), 22 \%(\mathrm{w} / \mathrm{w}) \mathrm{H}_{2} \mathrm{SO}_{4}$ silica gel $(3 \mathrm{~g}), 44 \%(\mathrm{w} / \mathrm{w}) \mathrm{H}_{2} \mathrm{SO}_{4}$ silica gel $(4 \mathrm{~g})$, silica gel $(0.6 \mathrm{~g})$ and $2 \%(\mathrm{w} / \mathrm{w}) \mathrm{KOH}$ silica gel $(2 \mathrm{~g})$ with $150 \mathrm{~mL}$ of DCM in hexane. The eluents were concentrated to approximately $200 \mu \mathrm{L}$ for instrumental analysis.

\subsection{Instrumental analysis and quality control}

Analyses of PCBs and PBDEs were performed with a gas chromatograph (GC, Agilent Technologies 6890; USA) coupled with a high resolution mass spectrometer (HRMS, JEOL 700D, Tokyo, Japan). For PCBs, the capillary column used was a DB5-MS column (60-m length, 0.25-mm inner diameter, 0.25- $\mu \mathrm{m}$ film thickness; J \& W Scientific, Palo Alto, CA, USA). Helium was used as the carrier gas at a flow rate of $1.2 \mathrm{~mL} \mathrm{~min}^{-1}$. The oven temperature program was $100^{\circ} \mathrm{C}$ for $4 \mathrm{~min}, 100$ to $180^{\circ} \mathrm{C}$ at $20^{\circ} \mathrm{C} \mathrm{min}-1,180^{\circ} \mathrm{C}$ for $10 \mathrm{~min}, 180$ to $300^{\circ} \mathrm{C}$ at $2^{\circ} \mathrm{C} \mathrm{min}{ }^{-1}, 300^{\circ} \mathrm{C}$ for $6.3 \mathrm{~min}^{-}$The injector temperature was $280^{\circ} \mathrm{C}$. One microliter of sample was injected in a splitless injection.

For PBDEs, the capillary column used was a DB5-MS column (30-m length, 0.25-mm inner diameter, 0.25- $\mu \mathrm{m}$ film thickness; J \& W Scientific, Palo Alto, CA, USA). Helium was used as the carrier gas at a flow rate of $1.0 \mathrm{~mL} \mathrm{~min}{ }^{-1}$. The oven temperature program was $100^{\circ} \mathrm{C}$ for $1 \mathrm{~min}, 100$ to $220^{\circ} \mathrm{C}$ at $20^{\circ} \mathrm{C} \mathrm{min}-1,220^{\circ} \mathrm{C}$ for $4 \mathrm{~min}, 220$ to $300^{\circ} \mathrm{C}$ at $8^{\circ} \mathrm{C} \mathrm{min}^{-1}, 300^{\circ} \mathrm{C}$ for $3 \mathrm{~min}$. The injector temperature was $260^{\circ} \mathrm{C}$. The $\mathrm{HRMS}$ was operated in electron ionization (EI) mode, and ions of individual PCBs and PBDEs were monitored by the selective ion monitoring (SIM) mode.

The accuracy of the method was determined by analyzing Certified Reference Materials (CRM) of a fish tissue (SRM 1946), from the US National Institute for Standards and Technology (NIST; Gaithersburg, MD, USA). The mean anlalyte concentrations found in the seven CRM samples were $71-105 \%$ and $68-98 \%$ of the certified PCB and PBDE concentrations, respectively. The mean recoveries of spiked surrogate internal standards of PCBs and PBDEs were $81 \pm 15 \%$, and $84 \pm 12 \%$ respectively. The calculated limits of detection (LOD, the concentration giving a signal-to-noise ratio of 3) were $0.001-0.023 \mathrm{ng} / \mathrm{g}$ for individual PCB congeners and $0.002-0.033 \mathrm{ng} / \mathrm{g}$ for individual PBDE congeners.

\subsection{Calculation of dietary intakes}

The intake of a grouping of PCBs or PBDEs ( $\mathrm{ng} / \mathrm{kg}$ body weight/day) in a seafood species by an 'average' Korean was calculated by multiplying the mean concentration of PCBs or PBDEs grouping ( $\mathrm{ng} / \mathrm{g}$ wet) in seafood species of interest by the mean daily per capita intake of the seafood species in Korea ( $\mathrm{g} /$ day) and dividing the result by mean body weight for Koreans (kg body weight). The concentrations of undetected compounds were considered as one-half of the respective LOD. Daily consumption rates of each seafood for the general population of Korea were obtained from the National Health and Nutrition Survey (MOHW 2011, 2015).

\section{Results And Discussion}

\subsection{Concentrations and profiles of PCBs}

Table 1 shows the concentrations of $\Sigma_{82} P C B, \Sigma_{6}$ NDL-PCB, $\Sigma_{12}$ DL-PCB, $\Sigma_{19} P B D E$, and $\Sigma_{7} P B D E$ in 31 seafood species widely consumed in Korea, 2015-2017. The concentrations of $\Sigma_{82}$ PCB were 0.06-6.69 ng/g wet, and CB-153 was present in the highest proportion (14 $\pm 2.9 \%$ ) among PCB congeners, followed by CB-138 (7.2 $\pm 1.8 \%)$, CB-118 (5.6 $\pm 1.6 \%)$, and CB-101 (5.0 $\pm 1.7 \%)$. Herring, eel, tuna and Spanish mackerel presented relatively high concentrations $(6.69,4.41,3.73$, and $3.68 \mathrm{ng} / \mathrm{g}$ wet, respectively) while the species with low levels were shrimp $(0.06 \mathrm{ng} / \mathrm{g}$ wet $)$ and abalone (0.07 ng/g wet). 
Table 1

Summary in concentrations of PCBs and PBDEs in seafood from Korea, 2015-2017

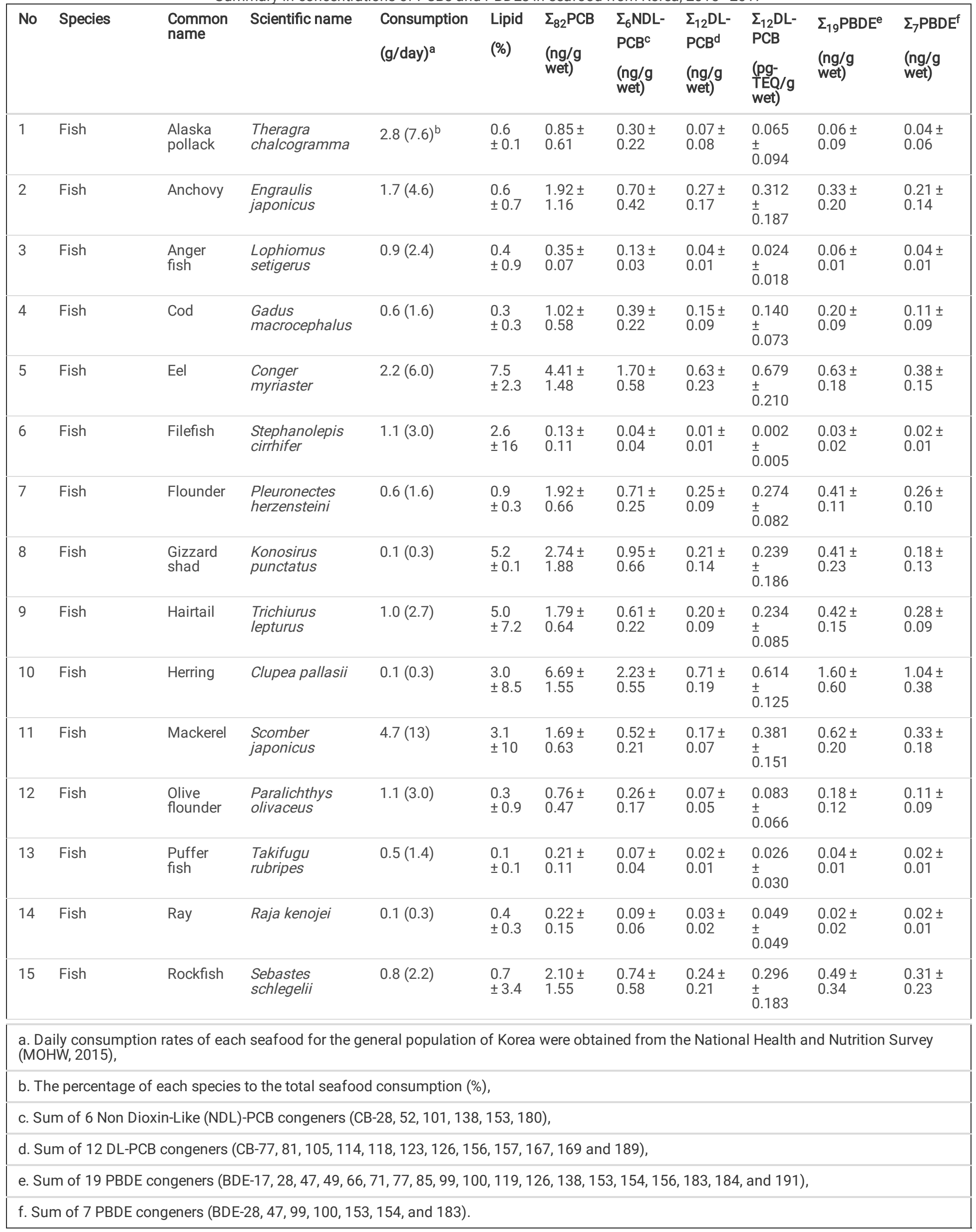




\begin{tabular}{|c|c|c|c|c|c|c|c|c|c|c|c|}
\hline No & Species & $\begin{array}{l}\text { Common } \\
\text { name }\end{array}$ & Scientific name & $\begin{array}{l}\text { Consumption } \\
(\mathrm{g} / \text { day })^{\mathrm{a}}\end{array}$ & $\begin{array}{l}\text { Lipid } \\
\text { (\%) }\end{array}$ & $\begin{array}{l}\Sigma_{82} \mathrm{PCB} \\
\text { (ng/g } \\
\text { wet) }\end{array}$ & $\begin{array}{l}\Sigma_{6} \mathrm{NDL}- \\
\mathrm{PCB}^{\mathrm{c}} \\
\text { (ng/g } \\
\text { wet) }\end{array}$ & $\begin{array}{l}\Sigma_{12} \mathrm{DL}- \\
\mathrm{PCB}^{\mathrm{d}} \\
\text { (ng/g } \\
\text { wet) }\end{array}$ & $\begin{array}{l}\Sigma_{12} \mathrm{DL}- \\
\mathrm{PCB} \\
(\mathrm{pg}- \\
\text { TEQ/g } \\
\text { wet) }\end{array}$ & $\begin{array}{l}\Sigma_{19} \mathrm{PBDE}^{\mathrm{e}} \\
\text { (ng/g } \\
\text { wet) }\end{array}$ & $\begin{array}{l}\Sigma_{7} \mathrm{PBDE}^{\mathrm{f}} \\
\text { (ng/g } \\
\text { wet) }\end{array}$ \\
\hline 16 & Fish & Saury & Cololabis saira & $0.9(2.4)$ & $\begin{array}{l}5.0 \\
\pm 2.5\end{array}$ & $\begin{array}{l}1.65 \pm \\
0.67\end{array}$ & $\begin{array}{l}0.54 \pm \\
0.22\end{array}$ & $\begin{array}{l}0.19 \pm \\
0.09\end{array}$ & $\begin{array}{l}0.418 \\
\pm \\
0.228\end{array}$ & $\begin{array}{l}0.65 \pm \\
0.28\end{array}$ & $\begin{array}{l}0.45 \pm \\
0.19\end{array}$ \\
\hline 17 & Fish & Sea bass & $\begin{array}{l}\text { Lateolabrax } \\
\text { jaonicus }\end{array}$ & $0.1(0.3)$ & $\begin{array}{l}2.9 \\
\pm 1.8\end{array}$ & $\begin{array}{l}2.22 \pm \\
1.22\end{array}$ & $\begin{array}{l}0.77 \pm \\
0.39\end{array}$ & $\begin{array}{l}0.23 \pm \\
0.13\end{array}$ & $\begin{array}{l}0.289 \\
\pm \\
0.212\end{array}$ & $\begin{array}{l}0.57 \pm \\
0.33\end{array}$ & $\begin{array}{l}0.35 \pm \\
0.20\end{array}$ \\
\hline 18 & Fish & $\begin{array}{l}\text { Spanish } \\
\text { mackerel }\end{array}$ & $\begin{array}{l}\text { Scomberomorus } \\
\text { niphonius }\end{array}$ & $0.6(1.6)$ & $\begin{array}{l}8.3 \\
\pm 2.2\end{array}$ & $\begin{array}{l}3.68 \pm \\
0.92\end{array}$ & $\begin{array}{l}1.20 \pm \\
0.31\end{array}$ & $\begin{array}{l}0.38 \pm \\
0.14\end{array}$ & $\begin{array}{l}0.721 \\
\pm \\
0.246\end{array}$ & $\begin{array}{l}1.00 \pm \\
0.26\end{array}$ & $\begin{array}{l}0.50 \pm \\
0.21\end{array}$ \\
\hline 19 & Fish & Tuna & $\begin{array}{l}\text { Thunnus } \\
\text { thynnus }\end{array}$ & $0.8(2.2)$ & $\begin{array}{l}0.4 \\
\pm 0.6\end{array}$ & $\begin{array}{l}3.73 \pm \\
2.91\end{array}$ & $\begin{array}{l}1.32 \pm \\
1.05\end{array}$ & $\begin{array}{l}0.43 \pm \\
0.36\end{array}$ & $\begin{array}{l}0.475 \\
\pm \\
0.348\end{array}$ & $\begin{array}{l}0.80 \pm \\
0.60\end{array}$ & $\begin{array}{l}0.53 \pm \\
0.39\end{array}$ \\
\hline 20 & Fish & $\begin{array}{l}\text { Yellow } \\
\text { croaker }\end{array}$ & $\begin{array}{l}\text { Larimichthys } \\
\text { polyactis }\end{array}$ & $1.7(4.6)$ & $\begin{array}{l}3.4 \\
\pm 4.4\end{array}$ & $\begin{array}{l}0.54 \pm \\
0.19\end{array}$ & $\begin{array}{l}0.16 \pm \\
0.06\end{array}$ & $\begin{array}{l}0.05 \pm \\
0.02\end{array}$ & $\begin{array}{l}0.046 \\
\pm \\
0.029\end{array}$ & $\begin{array}{l}0.14 \pm \\
0.06\end{array}$ & $\begin{array}{l}0.08 \pm \\
0.05\end{array}$ \\
\hline 21 & Crustaceans & Crab & $\begin{array}{l}\text { Portunus } \\
\text { trituberculatus }\end{array}$ & $1.7(4.6)$ & $\begin{array}{l}1.2 \\
\pm 5.7\end{array}$ & $\begin{array}{l}0.13 \pm \\
0.04\end{array}$ & $\begin{array}{l}0.05 \pm \\
0.02\end{array}$ & $\begin{array}{l}0.01 \pm \\
0.01\end{array}$ & $\begin{array}{l}0.026 \\
\pm \\
0.017\end{array}$ & $\begin{array}{l}0.03 \pm \\
0.01\end{array}$ & $\begin{array}{l}0.02 \pm \\
0.01\end{array}$ \\
\hline 22 & Crustaceans & Shrimp & $\begin{array}{l}\text { Solenocera } \\
\text { melantho }\end{array}$ & $2.2(6.0)$ & $\begin{array}{l}0.6 \\
\pm 0.1\end{array}$ & $\begin{array}{l}0.06 \pm \\
0.02\end{array}$ & $\begin{array}{l}0.02 \pm \\
0.01\end{array}$ & $\begin{array}{l}0.01 \pm \\
0.01\end{array}$ & $\begin{array}{l}0.001 \\
\pm \\
0.001\end{array}$ & $\begin{array}{l}0.01 \pm \\
0.01\end{array}$ & $\begin{array}{l}0.01 \pm \\
0.01\end{array}$ \\
\hline 23 & Gastropods & Abalone & Nordotis discus & $0.4(1.1)$ & $\begin{array}{l}1.1 \\
\pm 1.0\end{array}$ & $\begin{array}{l}0.07 \pm \\
0.10\end{array}$ & $\begin{array}{l}0.03 \pm \\
0.04\end{array}$ & $\begin{array}{l}0.01 \pm \\
0.01\end{array}$ & $\begin{array}{l}0.004 \\
\pm \\
0.010\end{array}$ & $\begin{array}{l}0.02 \pm \\
0.03\end{array}$ & $\begin{array}{l}0.01 \pm \\
0.02\end{array}$ \\
\hline 24 & Bivalves & Ark shell & $\begin{array}{l}\text { Scapharca } \\
\text { subcrenata }\end{array}$ & $0.5(1.4)$ & $\begin{array}{l}6.1 \\
\pm 1.7\end{array}$ & $\begin{array}{l}0.15 \pm \\
0.03\end{array}$ & $\begin{array}{l}0.04 \pm \\
0.01\end{array}$ & $\begin{array}{l}0.01 \pm \\
0.01\end{array}$ & $\begin{array}{l}0.086 \\
\pm \\
0.016\end{array}$ & $\begin{array}{l}0.02 \pm \\
1.95\end{array}$ & $\begin{array}{l}0.02 \pm \\
0.01\end{array}$ \\
\hline 25 & Bivalves & Clam & $\begin{array}{l}\text { Tapes } \\
\text { philippinarum }\end{array}$ & $1.2(3.3)$ & $\begin{array}{l}3.6 \\
\pm 0.7\end{array}$ & $\begin{array}{l}0.21 \pm \\
0.11\end{array}$ & $\begin{array}{l}0.07 \pm \\
0.04\end{array}$ & $\begin{array}{l}0.01 \pm \\
0.01\end{array}$ & $\begin{array}{l}0.017 \\
\pm \\
0.020\end{array}$ & $\begin{array}{l}0.04 \pm \\
0.04\end{array}$ & $\begin{array}{l}0.03 \pm \\
0.03\end{array}$ \\
\hline 26 & Bivalves & Mussel & Mytilus edulis & $1.3(3.5)$ & $\begin{array}{l}7.2 \\
\pm 1.7\end{array}$ & $\begin{array}{l}0.37 \pm \\
0.20\end{array}$ & $\begin{array}{l}0.14 \pm \\
0.08\end{array}$ & $\begin{array}{l}0.03 \pm \\
0.02\end{array}$ & $\begin{array}{l}0.113 \\
\pm \\
0.077\end{array}$ & $\begin{array}{l}0.09 \pm \\
0.06\end{array}$ & $\begin{array}{l}0.07 \pm \\
0.05\end{array}$ \\
\hline 27 & Bivalves & Oyster & $\begin{array}{l}\text { Crassostrea } \\
\text { gigas }\end{array}$ & $0.9(2.4)$ & $\begin{array}{l}5.9 \\
\pm 1.1\end{array}$ & $\begin{array}{l}0.49 \pm \\
0.18\end{array}$ & $\begin{array}{l}0.16 \pm \\
0.06\end{array}$ & $\begin{array}{l}0.03 \pm \\
0.01\end{array}$ & $\begin{array}{l}0.203 \\
\pm \\
0.119\end{array}$ & $\begin{array}{l}0.14 \pm \\
0.13\end{array}$ & $\begin{array}{l}0.09 \pm \\
0.07\end{array}$ \\
\hline 28 & Cephalopods & $\begin{array}{l}\text { Giant } \\
\text { octopus }\end{array}$ & $\begin{array}{l}\text { Enteroctopus } \\
\text { dofleini }\end{array}$ & $0.6(1.6)$ & $\begin{array}{l}0.3 \\
\pm 0.1\end{array}$ & $\begin{array}{l}0.21 \pm \\
0.07\end{array}$ & $\begin{array}{l}0.08 \pm \\
0.03\end{array}$ & $\begin{array}{l}0.03 \pm \\
0.01\end{array}$ & $\begin{array}{l}0.037 \\
\pm \\
0.021\end{array}$ & $\begin{array}{l}0.02 \pm \\
0.01\end{array}$ & $\begin{array}{l}0.02 \pm \\
0.01\end{array}$ \\
\hline 29 & Cephalopods & Octopus & Octopus minor & $2.0(5.4)$ & $\begin{array}{l}0.6 \\
\pm 0.5\end{array}$ & $\begin{array}{l}0.18 \pm \\
0.06\end{array}$ & $\begin{array}{l}0.07 \pm \\
0.02\end{array}$ & $\begin{array}{l}0.02 \pm \\
0.01\end{array}$ & $\begin{array}{l}0.020 \\
\pm \\
0.024\end{array}$ & $\begin{array}{l}0.03 \pm \\
0.01\end{array}$ & $\begin{array}{l}0.02 \pm \\
0.01\end{array}$ \\
\hline 30 & Cephalopods & $\begin{array}{l}\text { Webfoot } \\
\text { octopus }\end{array}$ & $\begin{array}{l}\text { Octopus } \\
\text { ocellatus }\end{array}$ & $0.2(0.5)$ & $\begin{array}{l}0.6 \\
\pm 0.4\end{array}$ & $\begin{array}{l}0.21 \pm \\
0.21\end{array}$ & $\begin{array}{l}0.07 \pm \\
0.07\end{array}$ & $\begin{array}{l}0.02 \pm \\
0.02\end{array}$ & $\begin{array}{l}0.020 \\
\pm \\
0.016\end{array}$ & $\begin{array}{l}0.04 \pm \\
0.04\end{array}$ & $\begin{array}{l}0.03 \pm \\
0.03\end{array}$ \\
\hline
\end{tabular}

a. Daily consumption rates of each seafood for the general population of Korea were obtained from the National Health and Nutrition Survey (MOHW, 2015),

b. The percentage of each species to the total seafood consumption (\%),

C. Sum of 6 Non Dioxin-Like (NDL)-PCB congeners (CB-28, 52, 101, 138, 153, 180),

d. Sum of 12 DL-PCB congeners (CB-77, 81, 105, 114, 118, 123, 126, 156, 157, 167, 169 and 189),

e. Sum of 19 PBDE congeners (BDE-17, 28, 47, 49, 66, 71, 77, 85, 99, 100, 119, 126, 138, 153, 154, 156, 183, 184, and 191),

f. Sum of 7 PBDE congeners (BDE-28, 47, 99, 100, 153, 154, and 183). 


\begin{tabular}{|c|c|c|c|c|c|c|c|c|c|c|c|}
\hline No & Species & $\begin{array}{l}\text { Common } \\
\text { name }\end{array}$ & Scientific name & $\begin{array}{l}\text { Consumption } \\
(\mathrm{g} / \text { day })^{\mathrm{a}}\end{array}$ & $\begin{array}{l}\text { Lipid } \\
\text { (\%) }\end{array}$ & $\begin{array}{l}\Sigma_{82} \mathrm{PCB} \\
(\mathrm{ng} / \mathrm{g} \\
\text { wet) }\end{array}$ & $\begin{array}{l}\Sigma_{6} \mathrm{NDL}- \\
\mathrm{PCB}^{\mathrm{C}} \\
\text { (ng/g } \\
\text { wet) }\end{array}$ & $\begin{array}{l}\Sigma_{12} \mathrm{DL}- \\
\mathrm{PCB}^{\mathrm{d}} \\
\text { (ng/g } \\
\text { wet) }\end{array}$ & $\begin{array}{l}\Sigma_{12} \mathrm{DL}- \\
\mathrm{PCB} \\
\text { (pg- } \\
\text { TEQ/g } \\
\text { wet) }\end{array}$ & $\begin{array}{l}\Sigma_{19} \mathrm{PBDE}^{\mathrm{e}} \\
\text { (ng/g } \\
\text { wet) }\end{array}$ & $\begin{array}{l}\Sigma_{7} \mathrm{PBDE}^{\mathrm{f}} \\
(\mathrm{ng} / \mathrm{g} \\
\text { wet) }\end{array}$ \\
\hline 31 & Cephalopods & Squid & $\begin{array}{l}\text { Todaroldes } \\
\text { pacificus }\end{array}$ & $6.2(17)$ & $\begin{array}{l}1.3 \\
\pm 0.5\end{array}$ & $\begin{array}{l}0.70 \pm \\
0.15\end{array}$ & $\begin{array}{l}0.23 \pm \\
0.05\end{array}$ & $\begin{array}{l}0.09 \pm \\
0.02\end{array}$ & $\begin{array}{l}0.082 \\
\pm \\
0.015\end{array}$ & $\begin{array}{l}0.09 \pm \\
0.02\end{array}$ & $\begin{array}{l}0.07 \pm \\
0.02\end{array}$ \\
\hline \multicolumn{12}{|c|}{$\begin{array}{l}\text { a. Daily consumption rates of each seafood for the general population of Korea were obtained from the National Health and Nutrition Survey } \\
\text { (MOHW, 2015), }\end{array}$} \\
\hline \multicolumn{12}{|c|}{ b. The percentage of each species to the total seafood consumption (\%), } \\
\hline \multicolumn{12}{|c|}{ c. Sum of 6 Non Dioxin-Like (NDL)-PCB congeners (CB-28, 52, 101, 138, 153, 180), } \\
\hline \multicolumn{12}{|c|}{ d. Sum of 12 DL-PCB congeners (CB-77, 81, 105, 114, 118, 123, 126, 156, 157, 167, 169 and 189), } \\
\hline \multicolumn{12}{|c|}{ e. Sum of 19 PBDE congeners (BDE-17, 28, 47, 49, 66, 71, 77, 85, 99, 100, 119, 126, 138, 153, 154, 156, 183, 184, and 191), } \\
\hline \multicolumn{12}{|c|}{ f. Sum of 7 PBDE congeners (BDE-28, 47, 99, 100, 153, 154, and 183). } \\
\hline
\end{tabular}

The levels of $\Sigma_{6} \mathrm{NDL}-\mathrm{PCB}$ were $0.02-2.23 \mathrm{ng} / \mathrm{g}$ wet, and CB-153 contributed more than $41 \%$ to the $\Sigma_{6} \mathrm{NDL}-\mathrm{PCB}$ (Fig. 1). The levels of $\Sigma_{6} \mathrm{NDL}-\mathrm{PCB}$ contributed $35 \%$ to the $\Sigma_{82} P C B$, and the levels of $\Sigma_{6}$ NDL-PCB were strongly correlated with those of $\Sigma_{82} P C B(r=0.997, p<0.01)$. Herring, eel, tuna, and Spanish mackerel also showed the highest concentrations of $\Sigma_{6}$ NDL-PCB. None of the samples showed concentrations of $\Sigma_{6}$ NDL-PCB above the European Union threshold concentrations, set at $75 \mathrm{ng} / \mathrm{g}$ wet for fish and $300 \mathrm{ng} / \mathrm{g}$ wet for eels (Official Journal of the European Union 2011). The levels of $\Sigma_{6}$ NDL-PCB in this study was lower than those in Polish Baltic fishing area (Piskorska-Pliszczynska et al. 2012), Catalonia of Spain (Perelló et al. 2015), four areas (South China Sea, Bohai Sea, East China Sea, and Yellow Sea) of China (Liu et al. 2011; Qian et al. 2017), three areas (Adriatic, Ionian, and Tyrrhenian seas) of Italy (Miniero et al. 2014) and nationwide survey of France (Arnich et al. 2009), shown in Table 2. 
Table 2

The concentrations of PCBs and PBDEs in seafood from many countries

\begin{tabular}{|c|c|c|c|c|c|c|}
\hline Country & Species & $\begin{array}{l}\text { Sampling } \\
\text { year }\end{array}$ & $\begin{array}{l}\Sigma_{6} \text { NDL- } \\
\text { PCB }^{a} \\
\text { (ng/g wet) }\end{array}$ & $\begin{array}{l}\Sigma_{12} \text { DL-PCB } \\
\text { (pg-TEQ/g } \\
\text { wet) }\end{array}$ & $\begin{array}{l}\Sigma_{7} \mathrm{PBDE}^{\mathrm{c}} \\
\text { (ng/g wet) }\end{array}$ & Reference \\
\hline Poland & 5 Fish species $(n=177)$ & $2006-2010$ & $1.11-38.7$ & $0.64-6.07$ & & Piskorska-Pliszczynska et al. (2012) \\
\hline Sweden & 13 Fish/fish products & 2005 & & $\begin{array}{l}0.177- \\
0.355\end{array}$ & & Törnkvist et al. (2011) \\
\hline \multirow[t]{2}{*}{ Spain } & 14 Seafood species & 2006 & \multirow{2}{*}{$\begin{array}{l}2.16- \\
49.95\end{array}$} & \multirow[t]{2}{*}{$0.17-1.99$} & \multirow[t]{2}{*}{$0.01-1.62^{d}$} & \multirow{2}{*}{$\begin{array}{l}\text { Domingo et al. (2008), Perelló et al. } \\
\text { (2015) }\end{array}$} \\
\hline & 14 Seafood species $(n=384)$ & 2012 & & & & \\
\hline France & Seafood $(n=1,119)$ & $2002-2006$ & $0.03-1,157$ & & & Arnich et al. (2009) \\
\hline Italy & $\begin{array}{l}14 \text { Fish/crustacean species } \\
(n=40)\end{array}$ & $2007-2008$ & $0.768-148$ & $0.027-11.8$ & $0.06-2.98$ & Miniero et al. (2014) \\
\hline US & 18 Fish species $(n=470)$ & $2006-2013$ & & & $\begin{array}{l}1-390^{e} \\
300)^{f}\end{array}$ & Gandhi et al. (2017) \\
\hline Japan & 9 Fish/shellfish $(n=18)$ & 1998 & & $0.033-7.24$ & & Naito et al. (2003) \\
\hline \multirow[t]{2}{*}{ China } & 30 Fish species $(n=44)$ & - & $0.3-2,972$ & & $0.2-476$ & Liu et al. (2011), Qian et al. (2017) \\
\hline & 17 Seafood species $(n=289)$ & 2014 & $<$ LOD-64 & & & \\
\hline Australia & 24 Seafood species $(n=24)$ & - & & & $0.61-21.39^{d}$ & Shanmuganathan et al. (2011) \\
\hline $\begin{array}{l}\text { East } \\
\text { Africa }\end{array}$ & 2 Fish species $(n=64)$ & 2011 & & $0.001-0.02$ & & Ssebugere et al. (2013) \\
\hline Korea & 31 Seafood species $(n=230)$ & $2015-2017$ & $0.04-2.23$ & $\begin{array}{l}0.002- \\
0.721\end{array}$ & $0.01-1.04$ & This study \\
\hline \multicolumn{7}{|c|}{ a. Sum of 6 Non Dioxin-Like (NDL)-PCB congeners (CB-28, 52, 101, 138, 153, 180), } \\
\hline \multicolumn{7}{|c|}{ b. Sum of 12 DL-PCB congeners (CB-77, 81, 105, 114, 118, 123, 126, 156, 157, 167, 169 and 189), } \\
\hline \multicolumn{7}{|c|}{ c. Sum of 7 PBDE congeners (BDE-28, 47, 99, 100, 153, 154, and 183), } \\
\hline \multicolumn{7}{|c|}{ d. Sum of 6 PBDE congeners (BDE-47, 99, 100, 153, 154, and 183), } \\
\hline \multicolumn{7}{|c|}{ e. Sum of 33 PBDE congeners, } \\
\hline f. BDE-47. & & & & & & \\
\hline
\end{tabular}

The levels of $\Sigma_{12}$ DL-PCB were $0.01-0.71 \mathrm{ng} / \mathrm{g}$ wet and CB-118 contributed $55 \%$ to $\Sigma_{12} \mathrm{DL}-\mathrm{PCB}$. The levels of $\Sigma_{12} \mathrm{DL}-\mathrm{PCB}$ contributed $10 \%$ to the $\Sigma_{82} \mathrm{PCB}$, and the levels of $\Sigma_{12} \mathrm{DL}-\mathrm{PCB}$ were significantly correlated with those of $\Sigma_{82} \mathrm{PCB}(r=0.980, p<0.01)$. Based on the WHO-TEF values (2005), $\Sigma_{12}$ DL-PCB concentrations were $0.001-0.721 \mathrm{pg}-\mathrm{TEQ} / \mathrm{g}$ wet, and the dominant congeners were CB-126 (89 $\left.\pm 6.2 \%\right)$, which has the highest toxic equivalent factor (TEF 0.1) among DL-PCBs, followed by CB-169 (8.4 $\pm 6.3 \%)$. Spanish mackerel (0.721 pg-TEQ/g wet), eel (0.679 pg-TEQ/g wet), herring ( $0.614 \mathrm{pg}-\mathrm{TEQ} / \mathrm{g}$ wet), and tuna ( $0.475 \mathrm{pg}-\mathrm{TEQ} / \mathrm{g}$ wet) showed high concentrations of DL-PCBs, similarly to NDL-PCBs. The European Union threshold concentrations of sum dioxins (PCDD/Fs + DL-PCBs) have been set at $6.5 \mathrm{pg}$-TEQ/g wet for fish and $10 \mathrm{pg}$-TEQ/g wet for eels (Official Journal of the European Union 2011). The contributions of four species (Spanish mackerel, eel, herring and tuna) to the threshold concentrations were 6.8-11\%, indicating that DL-PCB levels in seafood from Korea were safe. The levels of DL-PCBs in the present study were comparable to or lower than those in four major cities (Malmoe, Gothenburg, Uppsala and Sundsvall) of Sweden (Törnkvist et al. 2011), and Catalonia of Spain (Perelló et al. 2015), Ariake Sea of Japan (Naito et al. 2003), three areas (Adriatic, lonian, and Tyrrhenian seas) of Italy (Miniero et al. 2014), and Polish Baltic fishing area (Piskorska-Pliszczynska et al. 2012), shown in Table 2.

\subsection{Concentrations and profiles of PBDEs}

The concentrations of $\Sigma_{19}$ PBDE were $0.01-1.60 \mathrm{ng} / \mathrm{g}$ wet, and herring (1.60 $\mathrm{ng} / \mathrm{g}$ wet) was the species showing the highest PBDE level, followed by Spanish mackerel $\left(1.00 \mathrm{ng} / \mathrm{g}\right.$ wet) and tuna $(0.80 \mathrm{ng} / \mathrm{g}$ wet) (Table 1$)$. The $\Sigma_{19}$ PBDE and $\Sigma_{82} \mathrm{PCB}$ concentrations in the samples correlated significantly $(r=0.952, p<0.01)$. The result agrees with the findings in fish species and aquatic bird eggs (Liu et al. 2011; Manchester-Neesvig et al. 2001). Manchester-Neesvig et al. (2001) found that the concentrations of PBDEs and PCBs are highly correlated in individual fish, implying that PBDEs are as prevalent as PCBs in Lake Michigan. Liu et al. (2011) found that PBDEs have been in Chinese marine environment for many years and 
PBDE congeners (except for BDE-209), like PCBs, were distributed throughout the individual marine areas. This indicates that PBDEs, along with PCBs, were distributed throughout the coastal waters and have a similar accumulation pattern in seafood species.

The PBDE patterns in seafood and marine mammals are usually dominated by penta-mix formulation related congeners (Law et al. 2006; Moon et al. 2010). In the present study, $\Sigma_{7}$ PBDE (BDE-28, 47, 99, 100, 153, 154 and 183), which were related to PBDE Penta-mix (BDE-47, 99, 100, 153 and 154 ) and Octa-mix (BDE-183), showed the ranges of $0.01-1.04 \mathrm{ng} / \mathrm{g}$ wet, and contributed $66 \pm 9.3 \%$ to $\Sigma_{19} \mathrm{PBDE}$, and the levels of $\Sigma_{7} \mathrm{PBDE}$ were significantly correlated with those of $\Sigma_{19} \mathrm{PBDE}(r=0.990, p<0.01)$. It was found that the PBDE profile in seafood was BDE-47 (42\%) > BDE-154 (23\%) + BDE-153 (6.7\%) > BDE-100 (16\%) + BDE-99 (7.9\%) > BDE-28 (4.4\%) > BDE-183 (0.8\%) (Fig. 1). PBDE profiles in fish were generally as follows: BDE$47>$ BDE-99 + BDE-100 > BDE-153 + BDE-154 (Hites 2004). In fishes from Europe, these five congeners accounted for $69 \%, 28 \%$, and $8 \%$ of $\Sigma$ PBDE, respectively (Hites 2004). These profiles did not reflect the composition of penta-mix formulations, which contained 24-38\% tetra-BDEs (BDE-47), 50-60\% penta-BDEs (BDE-99 and 100), and 4-8\% hexa-BDEs (BDE-153 and 154; de Wit 2002). This might be associated with the differences in the uptake and removal efficiency of particular congeners. In uptake studies of PBDEs to pike (Burreau et al. 2004), BDE-47 was characterized by the highest uptake efficiency ( $90 \%$ of the given dose), followed by BDE-99 (62\%) and BDE-153 (40\%). Bioaccumulation studies of PBDEs in zebrafish also showed the highest accumulation of BDE-47 (de Wit 2002). In this study, BDE-154 was also found at relatively higher proportions than BDE-99 and BDE-100 in seafood species. It is similar to those in seafood from China (Xia et al. 2011). The reasons for the relative high proportion of BDE154 may be due to the extensive use of Octa-BDE rather than Penta-BDE and the debromination of higher brominated congeners, BDE-183 to BDE154 in fish species (Xia et al. 2011). In Korea, usage of octa-BDE (179 ton) in 2003 was 10 times higher than usage of penta-BDEs (19 ton) (MOE 2015).

The concentrations of $\Sigma_{7}$ PBDE (0.01-1.04 ng/g wet) in seafood in our study were similar to those reported from Catalonia of Spain (0.012-1.62 $\mathrm{ng} / \mathrm{g}$ wet, Domingo et al. 2008) and Italy (0.06-2.98ng/g wet; Miniero et al. 2014), but were lower than those reported from China (0.2-476 $\mathrm{ng} / \mathrm{g}$ wet, Liu et al., 2011), US (1-300 ng/g wet; Gandhi et al. 2017), and Australia (0.61-21.39 ng/g wet; Shanmuganathan et al. 2011).

\subsection{Human exposure from seafood consumption}

Table 3 shows the exposure of total PCBs and PBDEs by Korean population consuming seafood. The body weight, $59.8 \mathrm{~kg}$, was used to calculate the daily intakes for an average Korean. For Korean population, the dietary intakes of total PCB and 6 NDL-PCB were $45.2 \mathrm{ng} / \mathrm{day}(0.76 \mathrm{ng} / \mathrm{kg}$ bw/day) and $15.7 \mathrm{ng} /$ day ( $0.26 \mathrm{ng} / \mathrm{kg}$ bw/day), respectively. The high contributions to PCB and 6 NDL-PCB intake corresponded to eel and mackerel, with approximately $40 \%$ of the total. The dietary DL-PCB intake was $7.27 \mathrm{pg}-\mathrm{TEQ} / \mathrm{day}(0.12 \mathrm{pg}-\mathrm{TEQ} / \mathrm{kg} \mathrm{bw} / \mathrm{day})$, and the high contributions of DL-PCB intake were eel and mackerel, accounting collectively for approximately $45 \%$ of the total. The squid, anchovy, tuna, Spanish mackerel, and saury showed moderated contributions, accounting collectively for $30 \%$ of the total. This is associated with the relatively high consumption of this species as well as higher concentrations of PCBs in this species. In contrast, herring, showing the highest concentration, was the minor contributor due to the low consumption of herring, $0.1 \mathrm{~g} /$ day, in Korea. 
Table 3

Estimated human exposure of PCBs and PBDEs by the general population of Korea, 2015-2017

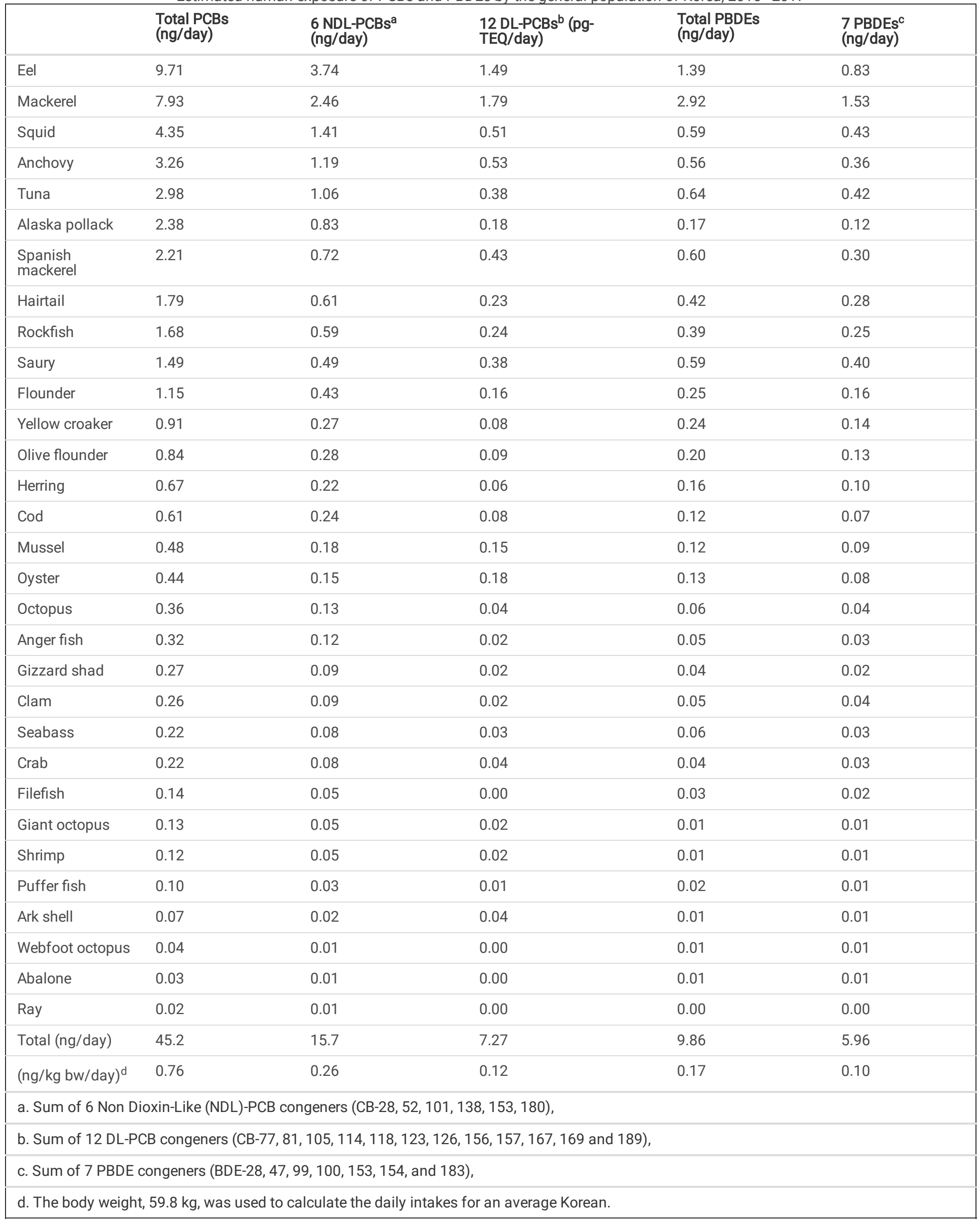


For the risk assessment of PCBs through seafood consumption, we compared with recommendations, TDIs (tolerable daily intake) and TWI (tolerable weekly intake) established by Korea, Denmark, and WHO. The total PCB intake (0.76 ng/kg bw/day) was approximately $3.8 \%$ of the TDI ( $20 \mathrm{ng} / \mathrm{kg}$ bw/day) by WHO in 2003, and $0.8 \%$ of the TDI (100 ng/kg bw/day) by Danish Veterinary and Food Administration in 2012 (Carlsson et al. 2014). The DL-PCB intake (0.12 pg-TEQ/kg bw/day) was 3.0\% of the TDI (4 pg-TEQ/kg bw/day) of dioxins (PCDD/Fs + DL-PCBs) by WHO and 6.0\% of the TWI (Tolerable Weekly Intake, 14 pg-TEQ/kg bw/week) by Korea Food and Drug Administration (KFDA) (Moon and Choi 2009). These results suggest that the human exposure to the PCBs and DL-PCBs through seafood intake in Korea is safe. If the PCDD/F concentrations are added to the DL-PCB concentrations in view of their dioxin-like toxicity, the combined concentrations do not exceed the TDI by WHO and TWI by KFDA because contribution of dietary intake of PCDD/Fs (average 30\% of DL-PCBs) was lower than DL-PCBs (Lee et al. 2007; Moon et al. 2009).

The total PBDE and 7 PBDE dietary intakes were $9.86 \mathrm{ng} /$ day $(0.17 \mathrm{ng} / \mathrm{kg}$ bw/day) and $5.96 \mathrm{ng} /$ day $(0.10 \mathrm{ng} / \mathrm{kg}$ bw/day), respectively. The high contributions to total PBDE and 7 PBDE intakes were also eel and mackerel, with approximately $40-45 \%$ of the total. The squid, tuna, Spanish mackerel, saury and anchovy also showed moderated contributions, accounting collectively for $30 \%$ of the total. To date, TDI levels have not been set for PBDEs by the EU due to limited data. A LOAEL (lowest observed adverse effect level) of $1 \mathrm{mg} / \mathrm{kg} / \mathrm{day}$ has been reported for the most sensitive toxic effects of PBDEs (Martí-Cid et al. 2007). Benchmark doses per day (computed and estimated "safe levels" of the PBDEs) are currently $309 \mu \mathrm{g} / \mathrm{kg}$ bw/day for BDE-47, $12 \mu \mathrm{g} / \mathrm{kg}$ bw/day for BDE-99, and $83 \mu \mathrm{g} / \mathrm{kg}$ bw/day for BDE-153 (EFSA 2011). The European Food Safety Authority concluded that only BDE-99 would be of potential health concern for the European population (EFSA 2011). In this study, the dietary intake of 7 PBDEs including BDE-47, BDE-99 and BDE-153 (0.10 ng/kg bw/day) was less than $1 \%$ of the safe levels. According to the LOAEL and safe levels, the PBDE intake through seafood results in a safety factor of various orders of magnitude.

\subsection{Temporal trends of concentrations of PCBs and PBDEs}

To investigate the temporal trends of PCBs and PBDEs in seafood (the same 23 species), the concentrations, seafood consumptions, and dietary intakes of these contaminants in our study were compared to those reported in the previous surveys (MLTM 2012; Moon and Choi 2009). Data of concentrations, seafood consumption, and dietary intakes of DL-PCBs and 19 PBDEs for Korean general population are shown in Figs. 2 and 3.

The levels of DL-PCB in seafood were $0.05-3.20$ pg-TEQ/g wet (mean: 0.87) in 2005-2007, 0.02-0.93 pg-TEQ/g wet (mean: 0.25) in 2010-2011, and $0.01-0.72 \mathrm{pg}-\mathrm{TEQ} / \mathrm{g}$ wet (mean: 0.24 ) in 2015-2017. The decreasing rate during the 12-year period was $73 \%$ in average concentrations of DLPCBs. The decreases of DL-PCB levels were observed in 22 of 23 species, and the declines in DL-PCB levels at more than $80 \%$, were observed in six species (hairtail, mackerel, tuna, yellow croaker, crab, and shrimp). Kim and Yoon (2014) reported that average concentrations of dioxins/furans in air samples of Korea decreased 15 times from $0.79 \mathrm{pg}-\mathrm{TEQ} / \mathrm{m}^{3}$ in 1999 to $0.052 \mathrm{pg}-\mathrm{TEQ} / \mathrm{m}^{3}$ in 2009, and of DL-PCBs also decreased 10 times during the periods of 1999-2009. Jeong et al. (2016) also reported that levels of DL-PCBs in finless porpoises inhabiting Korean coastal waters showed significant decrease of 60-68\% between 2003 and 2010 and regulations on POPs have been effective for marine mammals in Korea. Hence, these results indicated that reduction in PCB pollution might have occurred in Korea. A similar decreasing trends in PCB levels has recently reported in Indo-Pacific humpback dolphins (Sousa chinensis) collected from South China between 2004-2009 and 1995-2001 surveys, a representative biomonitor for contaminants in aquatic ecosystem (Wu et al. 2013). Sun et al. (2015) also reported that the PCB concentrations in two fish species from the Pearl River Estuary (South China) in 2013 were significantly lower than those in 2005 ( $p<0.05$ ), and declines of $61-80 \%$ were observed in two fish species during the 8-year period. This result indicates legislative actions on POPs such as PCBs have been effective in marine environments.

The levels of PBDEs in seafood were $0.02-1.55 \mathrm{ng} / \mathrm{g}$ wet (mean: 0.42) in 2010-2011, and 0.01-1.60 ng/g wet (mean: 0.35) in 2015-2017. The decreasing rate during the 7 -year period was $17 \%$ in average concentrations of PBDEs. The decreases of DL-PCB levels were observed in 14 of 23 species, and the declines in PBDE levels at more than $50 \%$, were observed in six species (anchovy, anger fish, mackerel, rockfish, crab, and shrimp). These results may reflect the ban on PBDEs and their decreased use due to the effectiveness of regulations and controls. In Korea, penta- and octaBDE were banned in 2008 and usage of deca-BDE decreased 9 times during the periods of 2002-2010 (MOE 2015). Gauthier et al. (2008) determined PBDEs in herring gull eggs from the Laurentian Great Lakes (1982-2006). PBDE congeners derived mainly from penta-BDE and octaBDE mixtures, BDE-47, -99 , and - 100, showed rapid increases up until 2000, however, there are no increasing trend post-2000, due to regulation of penta- and octa-BDE mixtures. Since their phase outs in the 2000s, PBDE levels in herring gull eggs of 2012-2013 were $30 \%$ lower than in herring gull eggs of 2006-2008 (Su et al. 2015). The declining PBDE trend for edible portions of fish was observed in Great Lakes between 2006/07 and 2012 (Gandhi et al. 2017). The levels of PBDEs in environmental media expected to decline further since regulatory actions.

\subsection{Temporal trends of human exposure}

Total dietary intake of DL-PCB was 45.6 pg-TEQ/day in the 2005-2007 survey, 11.3 pg-TEQ/day in 2010-2011 and 6.18 pg-TEQ/day in 2015-2017 (Fig. 3). The decreasing rate during the 12 -year period was $86 \%$ in total dietary intakes of DL-PCBs. The significant decreases of DL-PCB intakes between 2005-2007 and 2015-2017 surveys were found in four species, mackerel (15.8 pg-TEQ/day vs. 1.13 pg-TEQ/day), tuna (9.06 pg-TEQ/day vs. $0.55 \mathrm{pg}$-TEQ/day), hairtail (6.43 pg-TEQ/day vs. $0.34 \mathrm{pg}-\mathrm{TEQ} /$ day), and yellow croaker (3.64 pg-TEQ/day vs. 0.09 pg-TEQ/day), showing decreases of $93-98 \%$. These species were consistent with those showing high declines in DL-PCB levels (hairtail, mackerel, tuna, yellow croaker,

Page 10/15 
crab, and shrimp). Moreover, the four species showed decrease of $45-68 \%$ in consumption. Therefore, the decrease of human exposure to DL-PCBs is mainly due to the decrease in concentrations of DL-PCB in seafood, along with seafood consumption among the surveys.

The estimated exposures of 19 PBDEs through fish and seafood consumption are shown in Fig. 3. Higher intake of PBDEs, 20.4 ng/day, was found in the 2010-2011 survey (MLTM 2012), while in the subsequent survey investigation, the estimated intake of PBDEs has been declining to 8.67 ng/day in the 2015-2017 survey. The decreasing rate during the 7-year period was $58 \%$ in dietary intakes of PBDEs. The significant decreases were found in anchovy $(6.16 \mathrm{ng} /$ day vs. $0.51 \mathrm{ng} /$ day) and mackerel (6.05 ng/day vs. $1.87 \mathrm{ng} /$ day), showing decreases of $69-92 \%$. The decreasing rates of two species were $51-66 \%$ in PBDE concentrations and $37-75 \%$ in the consumption. The decrease of seafood intakes were found in 13 of 23 species and the decreasing rate was $27 \%$ in seafood consumption. Domingo et al. (2008) reported that the dietary intake of PBDEs through fish and shellfish intakes in Spain showed a decrease of $14 \%$ between 2000 and 2006, due to the decrease of $26 \%$ in fish and shellfish consumptions. Toms et al. (2018) analyzed serum pool concentrations of BDE 47, 99, 100 and 153 from 2002/03 to 2012/13, and reported that temporal trends were ageand congener-specific. Only two youngest age groups (0-4 and 5-15 year old) showed statistically significant decreases over the time, probably due to a decline in infant and toddler exposures in the indoor environment as use of PBDEs in consumer products has been phased out, however, older age groups showed no significant trend with time. These results indicate legislative actions on POPs have been effective in decrease of human exposure to POPs through seafood.

\section{Conclusions}

The exposures of Korean population to PCBs and PBDEs via seafood consumption have significantly decreased in 2015-2017, relative to those in 2005-2007 and 2010-2011. The significant decreases of PCB intakes were found in fatty fish such as mackerel, tuna, hairtail, yellow croaker, and anchovy. It is associated with the decrease in concentrations of PCBs and PBDEs in seafood between the surveys, due to regulatory actions. This indicates that levels and human exposure to PCBs and PBDEs from seafood consumption is expected to continue decreasing.

\section{Declarations}

\section{Acknowledgments}

This work was supported by a grant from the National Institute of Fisheries Science (R2019056). We thank our colleagues, Sera Yoon, Mi-Kyoung Lee, and Ye-Ji Kim for assistance with sampling and sample preparation.

\section{References}

1. Ankarberg E, Aune M, Concha G, Darnerud PO, Glynn A, Lignell S, Törnkvist A (2007) Risk assessment of persistent chlorinated and brominated environmental pollutants in food. Report 9-2007 National Food Administration

2. Arnich N, Tard A, Leblanc J, Le Bizec B, Narbonne J, Maimiline R (2009) Dietary intake of non-dioxin-like PCBs (NDL-PCBs) in France, Impact of maximum levels in some foodstuffs. Regul Toxicol Pharm 54:287-293

3. Burreau S, Zebühr Y, Broman D, Ishaq R (2004) Biomagnification of polychlorinated biphenyls (PCBs) and polybrominated diphenyl ethers (PBDEs) studied in pike (Esox Lucius), perch (Perca fluviatilis) and roach (Rutilus rutilus) from the Baltic Sea. Chemosphere 55:1043-4052

4. Carlsson P, Herzke D, Kallenborn R (2014) Polychlorinated biphenyls (PCBs), polybrominated diphenyl ethers (PBDEs) and perfluorinated alkylated substances (PFASs) in traditional seafood items from western Greenland. Environ Sci Pollut Res 21:4741-4750

5. Convention (2008) http://chm.pops.int/ [accessed in December 2020]

6. De Wit CA (2002) An overview of brominated flame retardants in the environment. Chemosphere 46:583-624

7. Domingo JL, Martí-Cid R, Castell V, Llobet JM (2008) Human exposure to PBDEs through the diet in Catalonia, Spain: Temporal trend: a review of recent literature on dietary PBDE intake. Toxicology 248:25-32

8. EFSA (2011) Scientific opinion on polybrominated diphenyl ethers (PBDEs) in Food. EFSA Journal European Food Safety Authority

9. Gandhi N, Bewurtz SB, Drouillard KG, Kolic T, MacPherson K, Reiner EJ, Bhavsar SP (2017) Polybrominated diphenyl ethers (PBDEs) in Great Lakes fish: levels, patterns, trends and implications for human exposure. Sci Total Environ 576:907-916

10. Gauthier LT, Hebert CE, Chip Weseloh DV, Letcher RJ (2008) Dramatic changes in the temporal trends of polybrominated diphenyl ethers (PBDEs) in Herring gull eggs from the Laurentian Great Lakes: 1982-2006. Environ Sci Technol 42:1524-1530

11. Hites RA (2004) Polybrominated diphenyl ethers in the environment and in people: a meta-analysis of concentrations. Environ Sci Technol 38:945-956

12. Jeong Y, Kim SJ, Shin KH, Hwang SY, An YR, Moon HB (2016) Accumulation and temporal changes of PCDD/Fs and dioxin-like PCBs in finless porpoises (Neophocaena asiaeorientalis) from Korean coastal waters: Tracking the effectiveness of regulation. Mar Pollut Bull 105:30-36

13. Kim SK, Yoon J (2014) Chronological trends of emission, environmental level and human exposure of POPs over the last 10 years (1999-2010) in Korea: Implication to science and policy. Sci Total Environ 470-471:1346-1361

Page $11 / 15$ 
14. Law RJ, Allchin CR, de Boer J, Coavci A, Herzke D, Lepom P, Morris S, Tronczynski J, de Wit C (2006) Levels and trends of brominated flame retardants in the European environment. Chemosphere 64:187-208

15. Lee KT, Lee JH, Lee JS, Park KH, Kim SK, Shim WJ (2007) Human exposure to dioxin-like compounds in fish and shellfish consumed in South Korea. Human Ecol Risk Assess 13:223-235

16. Leng L, Chen X, Li CP, Lux XY, Tang NJ (2014) 2,3,7,8-Tetrachlorodibenzo-p-dioxin exposure and prostate cancer: a meta-analysis of cohort studies. Public Health 128:207-213

17. Liu Y, Li J, Zhao Y, Wen S, Huang F, Wu Y (2011) Polybrominated diphenyl ethers (PBDEs) and indicator polychlorinated biphenyls (PCBs) in marine fish from four areas of China. Chemosphere 83:168-174

18. Manchester-Neesvig JB, Valters K, Sonzogni WC (2001) Comparison of polybrominated Diphenyl Ethers (PBDEs) and polychlorinated biphenyls (PCBs) in Lake Michigan Salmonids. Environ Sci Technol 35:1072-1077

19. Martí-Cid R, Bocio A, Llobet JM, Domingo JL (2007) Intake of chemical contaminants through fish and seafood consumption by children of Catalonia, Spain; Health risks. Food Chem Toxicol 45:1968-1974

20. Miniero R, Abate V, Brambilla G, Davoli E, de Felip E, de Filippis SP, Dellatte E, De Luca S, Fanelli, R, Fattore El, Ferri F, Fochi I, Fulgenzi AR, lacovella N, lamiceli AL, Lucchetti D, Melotti P, Moret I, Piazza R, Roncarati A, Ubaldi A, Zambon S, Di Domenico A (2014) Persistent toxic substances in Mediterranean aquatic species. Sci Total Environ 494-495:18-27

21. MOE (Ministry of Environment) (2015) A report on use and inventory of brominated flame retardants in Korea. Chemicals Management Association, Seoul. Korea

22. MOHW (Ministry of Health and Welfare) (2011) Report on 2010. National Health and Nutrition Survey: Ministry of Health and Welfare, Osong, Korea (In Korean)

23. MOHW (2015) Report on 2014. National Health and Nutrition Survey: Ministry of Health and Welfare, Osong, Korea (In Korean)

24. MLTM (Ministry of Land, Transport, and Maritime Affairs) (2012) Report on persistent organic pollutants in the marine ecosystem, Seoul, Korea (In Korean)

25. Moon HB, Choi HG (2009) Human exposure to PCDDs, PCDFs and dioxin-like PCBs associated with seafood consumption in Korea from 2005 to 2007. Environ Int 35:279-284

26. Moon HB, Kannan K, Choi M, Yu J, Choi HG, An YR, Choi SG, Park JY, Kim ZG (2010) Chlorinated and brominated contaminants including PCBs and PBDEs in minke whales and common dolphins from Korean coastal waters. J Hazard Mater 179:735-741

27. Moon HB, Kim HS, Choi M, Yu J, Choi HG (2009) Human exposure to polychlorinated biphenyls and organochlorine pesticides resulting from seafood consumption in South Korea, 2005-2007. Food Chem Toxicol 47:1819-1825

28. Naito W, Jin J, Kang Y, Yamamuro M, Masunaga S, Nakanishi J (2003) Dynamics of PCDDs/DFs and coplanar-PCBs in an aquatic food chain of Tokyo Bay. Chemosphere 53:347-362

29. Official Journal of the European Union (2011) Commission Regulation (EU) No 1259/2011 of 2 December 2011 amending Regulation (EC) No 1881/2006 as regards maximum levels for dioxins, dioxin-like PCBs and non dioxin-like PCBs in foodstuffs. L320/18-23

30. Perelló G, Díaz-Ferrero J, Llobet JM, Castell V, Vicente E, Nadal M, Domingo JL (2015) Human exposure to PCDD/Fs and PCBs through consumption of fish and seafood in Catalonia (Spain): Temporal trend. Food Chem Toxicol 81:28-33

31. Piskorska-Pliszczynska J, Maszewski S, Warenik-Bany M, Mikolajczyk S, Goraj L (2012) Survey of persistent organochlorine contaminants (PCDD, PCDF, and PCB) in fish collected from the Polish Baltic Fishing areas. Sci World J Article ID 973292, 7 pages

32. Qian Z, Luo F, Wu C, Zhao R, Cheng X, Qin W (2017) Indicator polychlorinated biphenyls (PCBs) and organochlorine pesticides (OCPs) in seafood from Xiamen (China): levels, distributions, and risk assessment. Environ Sci Pollut Res 24:10443-10453

33. Shanmuganathan D, Megharaj M, Chen Z, Naidu R (2011) Polybrominated diphenyl ethers (PBDEs) in marine foodstuffs in Australia: Residue levels and contamination status of PBDEs. Mar Pollut Bull 63:154-159

34. Sseburgere P, Kiremire BT, Henkelmann B, Bernhöft S, Kasozi GN, Wasswa J, Schramm K (2013) PCDD/Fs and dioxin-like PCBs in fish species from Lake Victoria, East Africa. Chemosphere 92:317-321

35. Su G, Letcher RJ, Moore JN, Williams LL, Martin PA, de Solla SR, Bowerman WW (2015) Spatial and temporal comparisons of legacy and emerging flame retardants in herring gull eggs from colonies spanning the Laurentian Great Lakes of Canada and United States. Environ Res $142: 720-730$

36. Sun R, Luo X, Tan X, Tang B, Li Z, Mai B (2015) An eight year (2005-2013) Temporal trend of halogenated organic pollutants in fish from the Pearl River Estuary, South China. Mar Pollut Bull 93:61-67

37. Toms LL, Sjödin A, Hobson P, Harden FA, Aylward LL, Mueller JF (2018) Temporal trends in serum polybrominated diphenyl ether concentrations in the Australian population, 2002-2013. Environ Int 121:357-364

38. Törnkvist A, Glynn A, Aune M, Darnerud PO, Ankarberg EH (2001) PCDD/F, PCB, PBDE, HBCD and chlorinated pesticides in a Swedish market basket from 2005 - levels and dietary intake estimations. Chemosphere 83:193-199 
39. Wu Y, Shi J, Zheng GJ, Li P, Liang B, Chen T, Wu Y, Liu W (2013) Evaluation of organochlorine contamination in Indo-Pacific humback dolphins (Sousa chinesnsis) from the Pearl River Estuary, China. Sci Total Environ 44:423-429

40. Xia C, Lam JCW, Wu X, Sun L, Xie Z, Lam PKS (2011) Levels and distribution of polybrominated diphenyl ethers (PBDEs) in marine fishes from Chinese coastal waters. Chemosphere 82:18-24

\section{Figures}

(a)

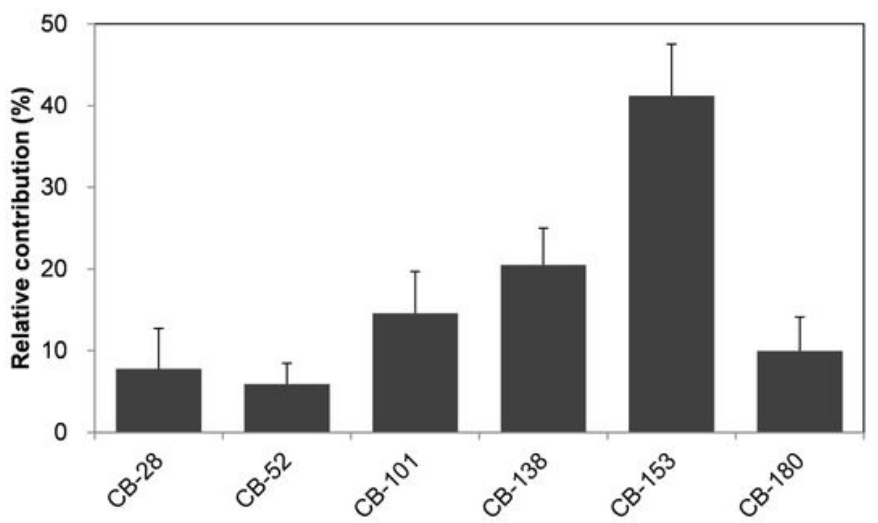

(c)

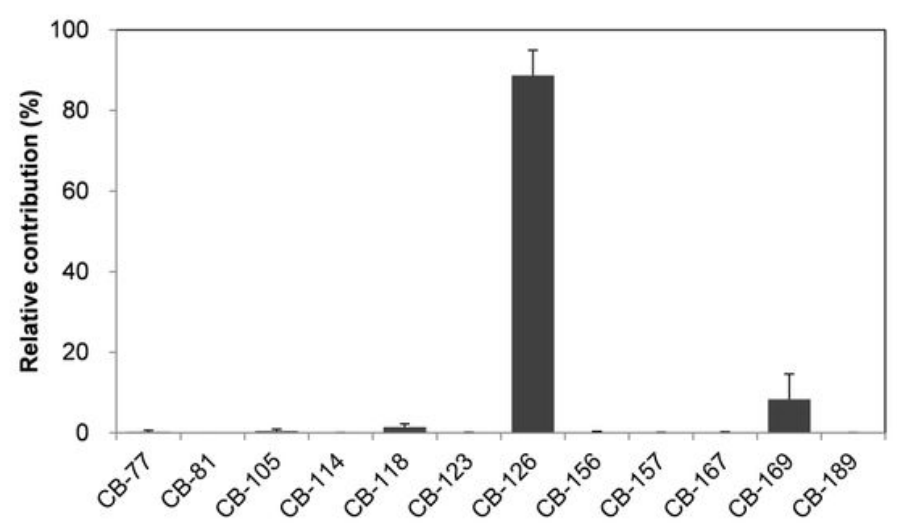

(b)

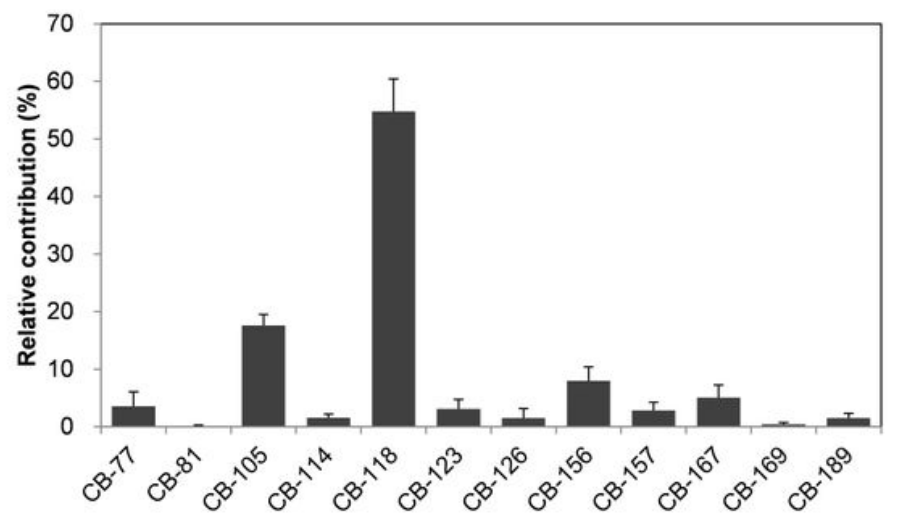

(d)

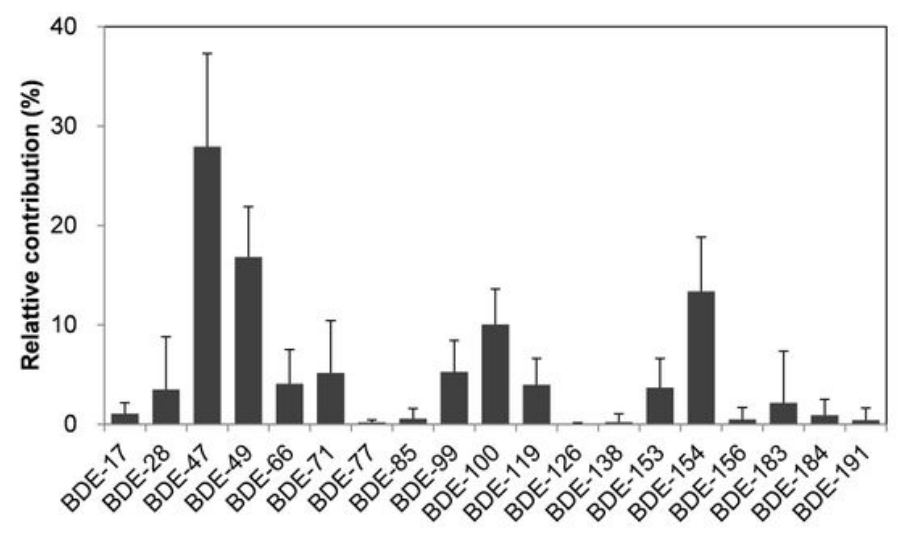

\section{Figure 1}

Relative contribution of (a) NDL-PCBs, (b) DL-PCBs (c) DL-PCBs (WHO-TEQ), and (d) PBDEs to their sum in seafood 
(a)

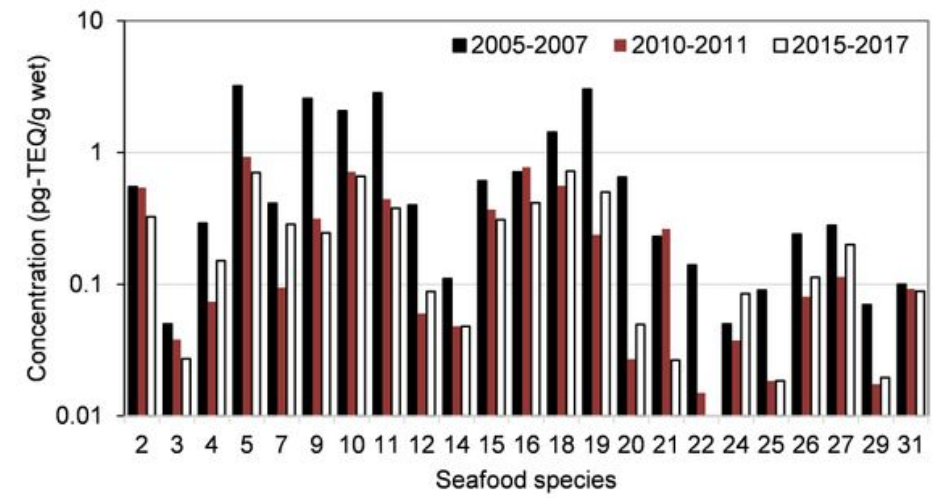

(c)

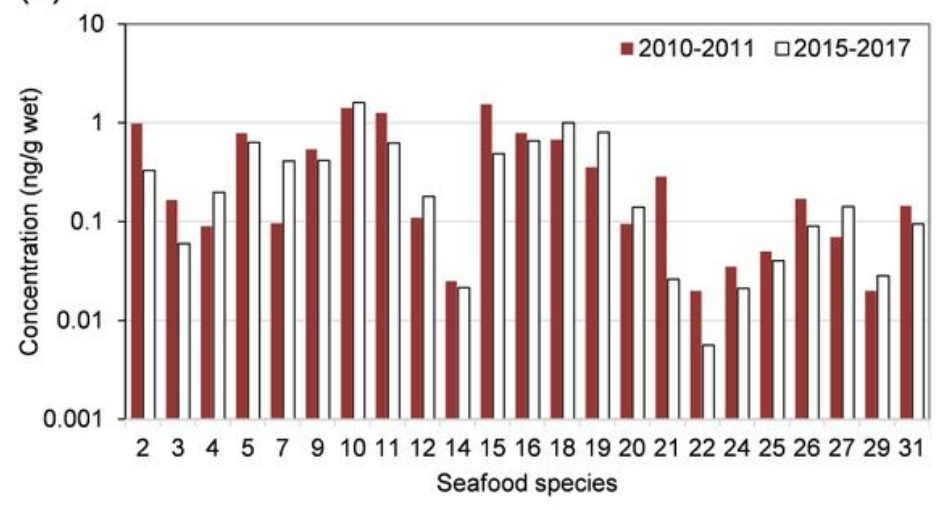

(b)

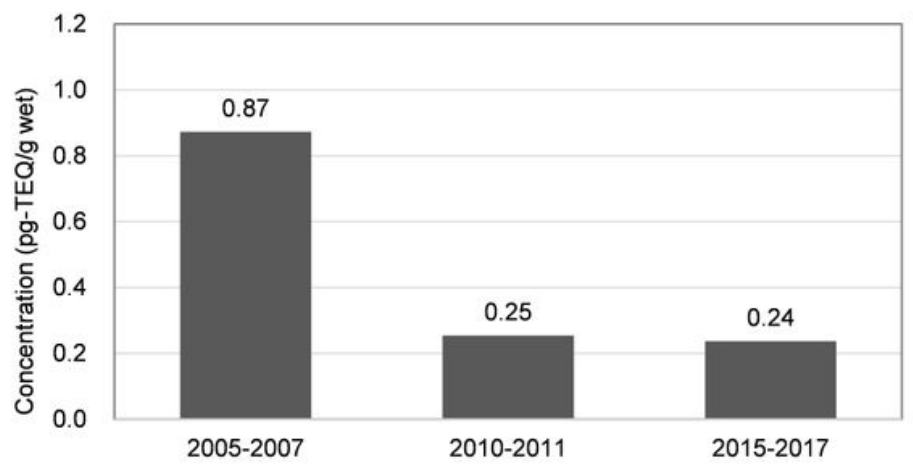

(d)

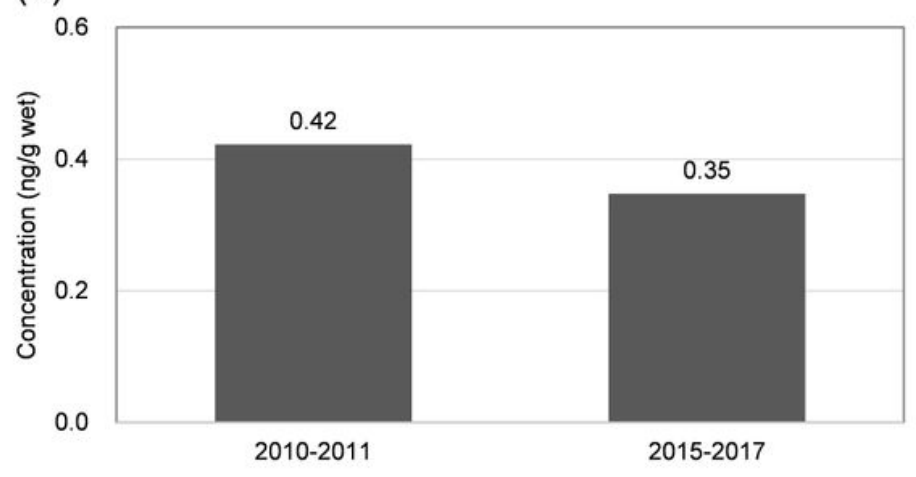

\section{Figure 2}

Temporal trend of (a) DL-PCB levels of each seafood species, (b) average DL-PCB levels of seafood, (c) PBDE levels of each seafood species, and (d) average PBDE levels of seafood in 2005-2017. The species names on the $x$-axes were presented in the same order as in Table 1 
(a)

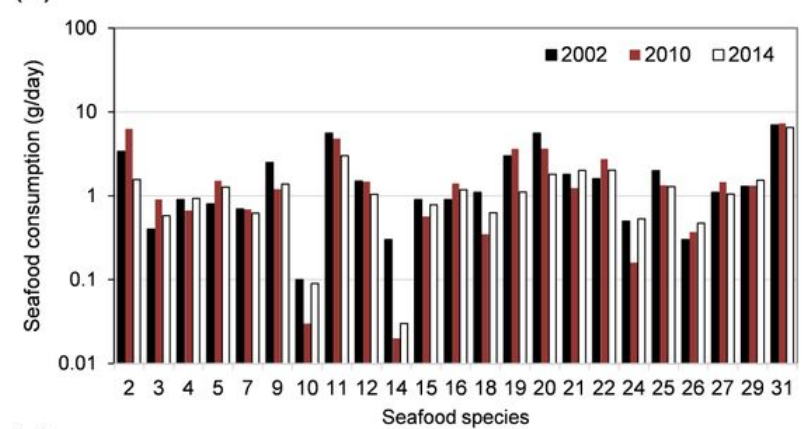

(c)

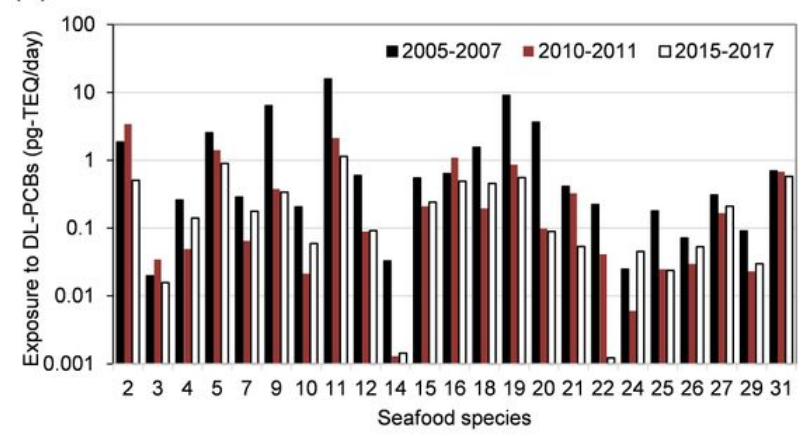

(e)

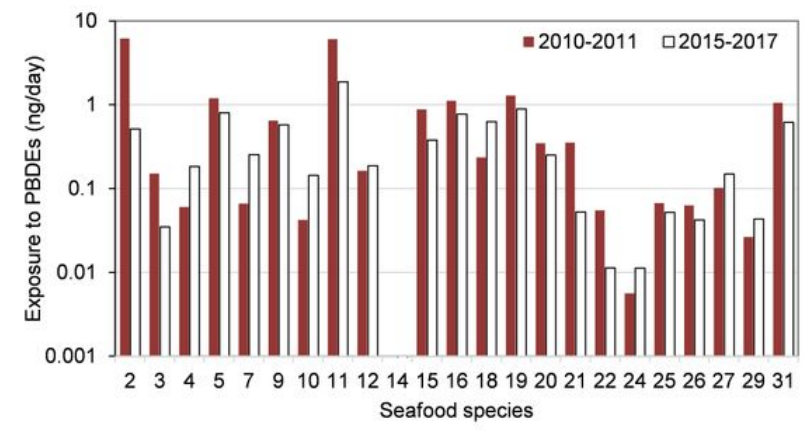

(b)

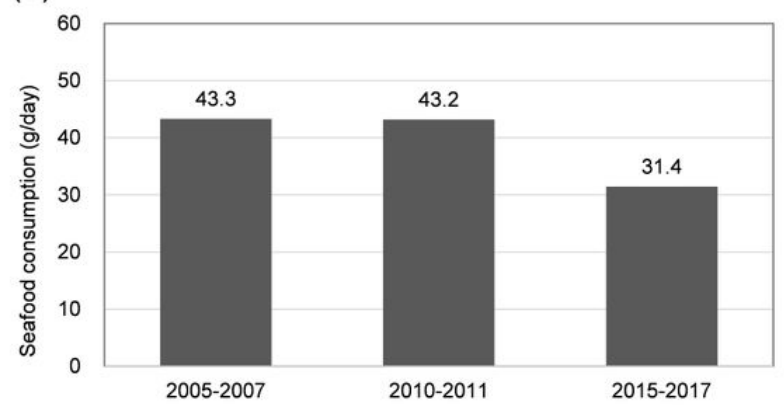

(d)

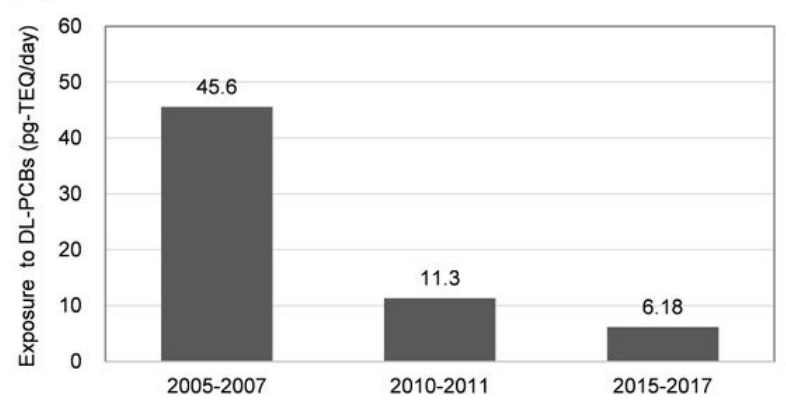

(f)

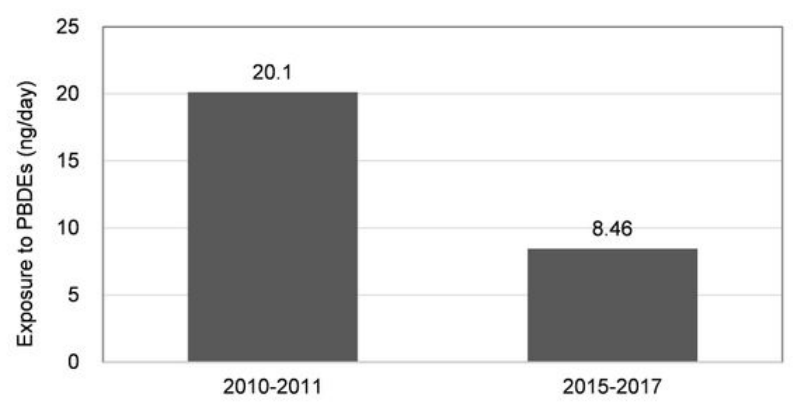

Figure 3

Temporal trend of (a) consumption for each seafood species and (b) total seafood consumption of Korean population, and dietary exposure of Korean population to DL-PCBs (c) by each seafood consumption and (d) by total seafood consumption, to PBDEs (e) by each seafood species and (f) by total seafood consumption. The species names on the $\mathrm{x}$-axes were presented in the same order as in Table 1 